\title{
REWILDING URBAN AREAS TO MAINTAIN ECOSYSTEM SERVICES AND ECOLOGICAL TOURISM: THE CASE OF SALER'S DEVESA, VALÈNCIA, SPAIN
}

\author{
JOSÉ LUIS MIRALLES I GARCIA \& FELIPE MARTÍNEZ LLORENS \\ Department of Urbanisme, Universitat Politècnica de València, Spain
}

\begin{abstract}
The Saler's Devesa is a case of a failed tourist project to urbanize a historical protected forest inside the metropolitan area of València in Spain. In the 1970s, the government started actions to urbanize this area. In fact, all the public works and some buildings were built. However, in the 1980s the new democratic government decided to rewild the area and "deconstruct" the urban development works that had already been built. The case allows knowing the process of rewilding and the difficulties to do it. On the other hand, currently in developed countries, metropolitan areas simultaneously present a stabilized population and a great surface extension. In this situation, the sustainability of these urban areas has focused on managing the city already consolidated by renovation or regeneration processes and rewilding open spaces, developing green infrastructures. Because of this, we focused our attention on researching one of the few cases that exists on rewilding urban areas. The green infrastructure concept has been used in the case of La Devesa to maintain and increase ecosystem services. In addition, these actions allow promotion of ecological tourism inside the area. The research question is "What should be the idea of society's progress when touristic urban development growth is no longer possible or desirable?" The article analyses the historical process of rewilding and rethinking the idea of progress in the current situation.
\end{abstract}

Keywords: rewilding cities, green infrastructures, ecological tourism, rewilding cost, metropolitan areas.

\section{INTRODUCTION}

The case of "La Devesa de l'Albufera" or Saler's Devesa is an exceptional case of urban area rewilding. "La Devesa" is a sand strip between the Albufera Lake (fresh water) and the Mediterranean Sea (salt water) close to Valencia City (Spain). This territory was occupied by a dense Mediterranean forest and, since medieval age, was public property, for a long time such as royal lands and after such as part of natural heritage of Valencia City Council. Even this land was historically protected because of Valencia City Council, in the 19th century and about the first half of the 20th century, couldn't use it for other uses different of natural forest.

In the 1960s, as part of public policy of Spanish state for touristic development, it was elaborated an urbanistic plan to build a new tourist town inside the forest after selling public property. Of course, this urbanization was going to destroy the forest and its ecosystem. Valencia City Council paid the cost of public works to urbanize the area and sold the plots to build. In fact the public works to urbanization was completely executed and also a part of buildings.

In the 1970s, social values changed along with the political system that changed from Franco's dictatorship to democracy in 1978. The first democratic government stopped the urbanization process and started the process to rewilding the area in accordance with their political programme.

This case has been analysed by Martínez Llorens in his $\mathrm{PhD}$ research [1] directed by $\mathrm{Dr}$ Josep Luís Miralles. This article shows a part of this research and use that to review or rethink the concept of progress in currently situation of metropolitan areas. 
Therefore this article is structured in four sections plus this introduction. Section 2 shows the general trends about metropolitan areas and the introduction of green infrastructure concept. In addition, the main characteristics of the case of "La Devesa" such as case of urban touristic development. Section 3 shows the methodology and data, specifically about the process of rewilding and it economic cost. Section 4 includes the results and it discussion. And finally, Section 5 shows the conclusions.

\section{FRAMEWORK AND LITERATURE REVIEW}

\subsection{Previous considerations}

The case of "La Devesa" is extraordinary because is a case of de-urbanization of an already urbanized land. In fact, it is a case of forest-ecosystem rewilding with a hard destruction by a building process for a touristic development. The objective now is to identify how our society can make the most of this experience to solve current problems or achieve new goals, particularly the sustainability of urban touristic development or urban development in general.

To achieve this goal we will focus our attention on three aspects:

- General evolution of metropolitan areas that concentrate the main social and economic activities especially as response of economic system to financial crisis of 2008.

- The use of green infrastructure as way to regenerate urban and metropolitan areas on sustainability conditions.

- The case of "La Devesa" as an example of the rewilding process allowing knowledge of the economic costs.

\subsection{Metropolitan trends}

According to different studies and various authors such as Vheeler [2], Aguilera et al. [3], Feria Toribio and Martínez Bernabeu [4] or Miralles i Garcia [5], etc., metropolitan areas in developed countries show a trend, especially since the 2008 economic crisis, with two main characteristics:

- Stabilised population or low increase;

- Very significant increase of extension or surface. That is, increase of towns next to central areas with commuter travels and consequently increase of surface extension.

This situation is sign that, social and economic activities have been increased more in metropolitan areas than other territorial areas such as rural areas or small-medium cities, of course, before the coronavirus crisis.

In addition, this trend implies the need of focus the attention on urban renovation as a system to improve or change urban uses in order to satisfy new urban demands. Of course, this thinking is coherent with sustainability urban goals against the historical trend of transformation rural landscapes into urban areas.

Fig. 1 shows the current extension of the metropolitan area of València in Spain. In it you can see the Albufera Lake and the "La Devesa del Saler" that is the land band between the lake and the Mediterranean Sea. You can see that these spaces, protected today, are inside the metropolitan area of València. Today these spaces are part of protected areas system because of different causes (natural ecosystems, agricultural areas, natural or historical heritages, etc.). Albufera Lake is a special case of wetland transformation to a semi-artificial 


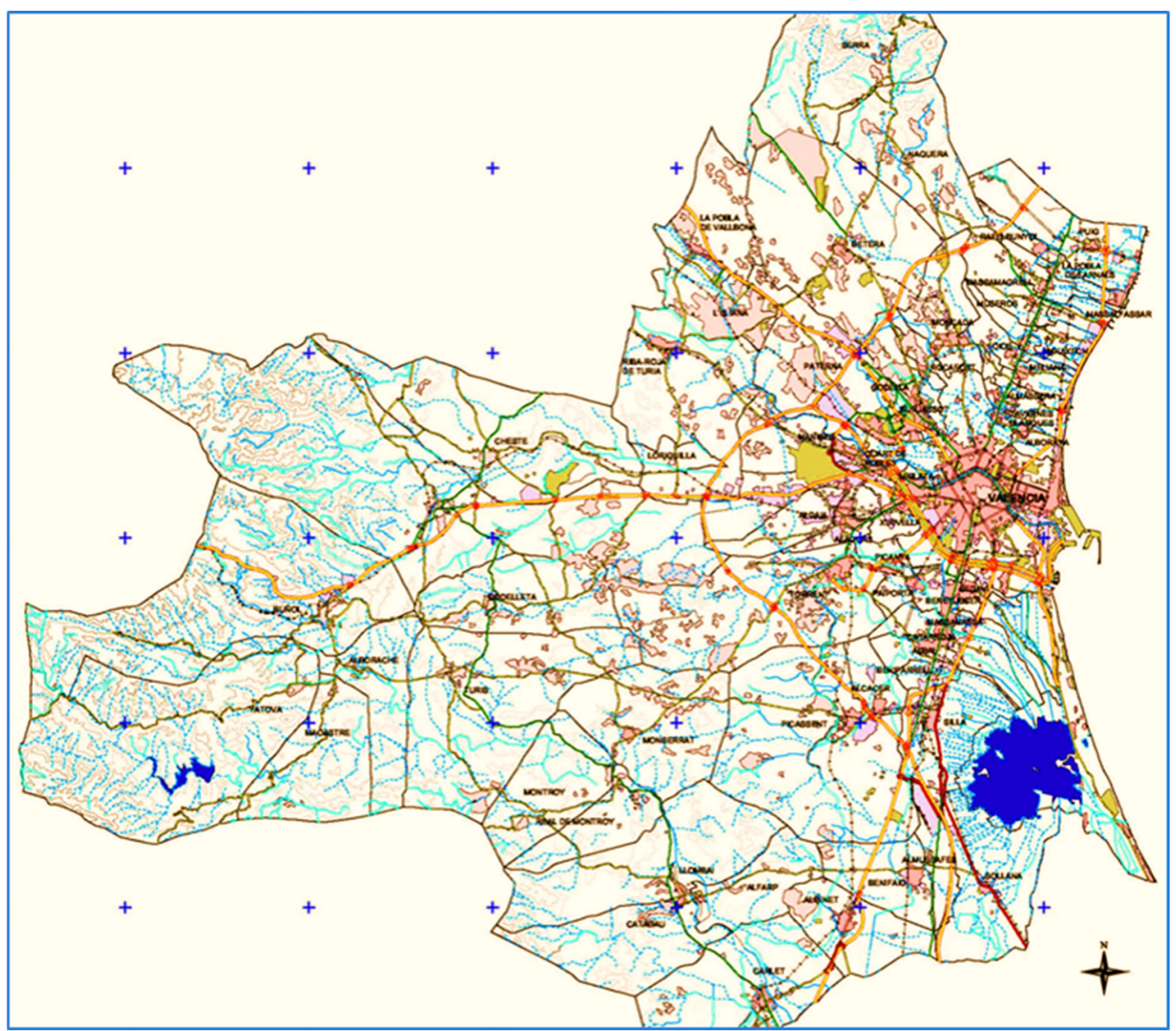

Figure 1: Metropolitan area of València. (Source: UDR F.Eiximenis.)

ecosystem [6]. In addition, there are a cities system and a large list of infrastructures, especially transports infrastructures, mostly designed from the only point of view of it function to serve cities but not to respect, maintain or promote the ecosystem services of land's sectors crossed by them.

As a consequence, within the framework of general trends in metropolitan areas, stabilized/low growth population, the sustainable urban growth to satisfy new demands of urban uses only is possible by urban renovation processes. If these new demands or urban uses are satisfied by building new rural areas instead, we will have more urban areas extension, more rural areas destructions and more abandoned urban areas because of the new urban areas replace activities located in other older urban areas that will be abandoned generating in this way degraded urban areas.

\subsection{The introduction of concept of green infrastructure}

Currently it is well known the concept of green infrastructure, consolidated in Europe since it definition by European Commission in 2013 [7]. The Green Infrastructure (GI) is a way to improve natural capital by it integration in territories, including urban and metropolitan areas, 
such as network of rural and natural lands connected between them. From this point of view, society can improve it sustainability connecting open spaces of urban and metropolitan areas between them.

Also in València this concept is being promoted protecting open spaces that generate ecosystems services and connecting these spaces between them. Some methodologies have been developed to identify and design the GI network in València [8], [9].

Particularly, in València there is a special historic agricultural land, today protected, that today is part of GI system of metropolitan area of València [10], [11]. Also GI is a way to improve sustainability in metropolitan areas where "urban sprawl" make unsustainable forms [12], [13].

Under this theoretical framework, only urban renovation is the way to change the current situation in order to improve the sustainability of urban and metropolitan areas redesigning GI network inside it, or like some authors say, rewilding urban and metropolitan areas.

\subsection{Urban touristic developments and the case of Saler's Devesa}

In Fig. 2 you can see an image of the touristic urban project designed by Cano Laso architect, according to proposals of Modern Architecture Movement, for urban development of "La Devesa" in 1963.

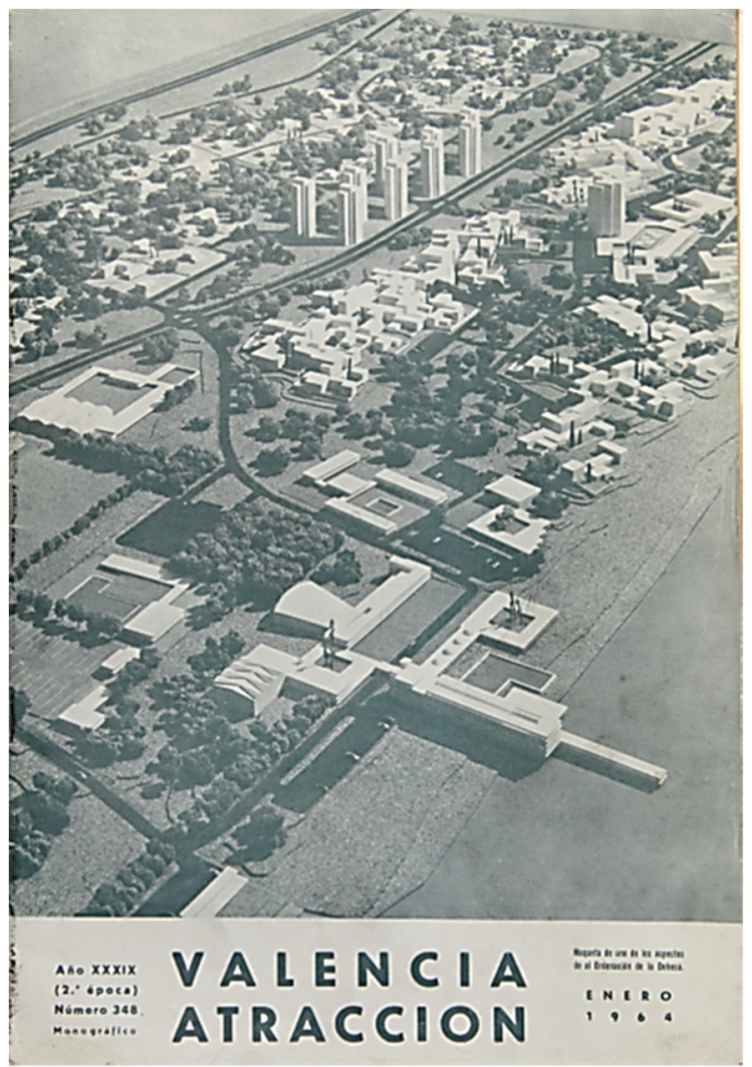

Figure 2: Cover of journal "Valencia atracción" with an image of touristic urban project, January 1964. (Source: Municipal Newspaper Archive of Valencia.) 
The urbanization project of "La Devesa del Saler" or Saler's Devesa, was a project to urbanize a coastal area such as way to promote tourism and obtain foreign currency in Spain in the 1960s, in the period of Franco dictator. The case is very interesting because the land was public domain, the whole of public works were executed and paid by city council, a lot of plots was sold to build and a part of them were built. However, in the 1980s, the first democratic municipal government, according to a political program, began the action to return land to city council and rewilding the original ecosystem. It is a case of green infrastructure renovation to maintain a very important ecosystem, its ecological services and, particularly a big natural beach close to Valencia City.

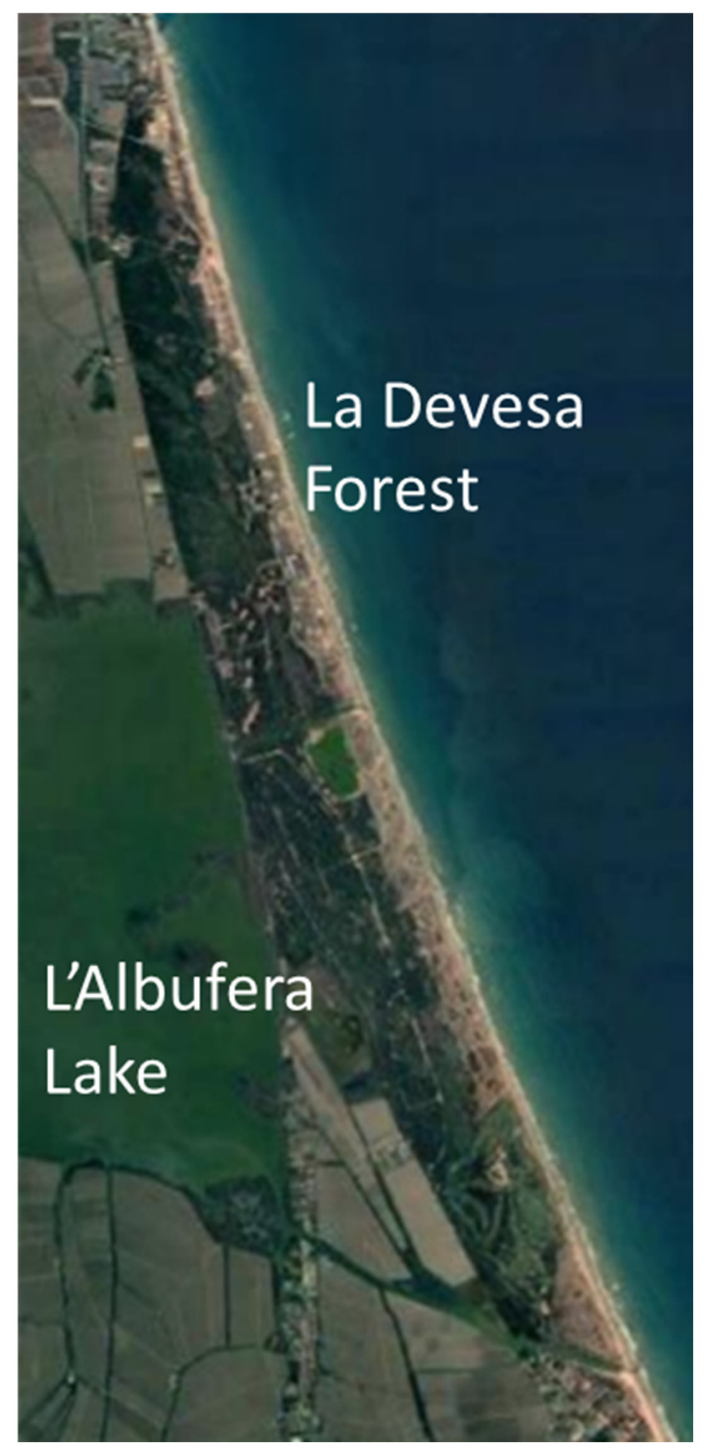

Figure 3: "La Devesa" forest today, with a part already urbanized and built on. (Source: Google Earth, 05/05/2019 satellite image.) 
The case has been analysed by Martínez Llorens in his Doctoral thesis [1]. It is one of the few cases of rewilding a public forest protected since medieval age and sold to promote a touristic urban area justified on the idea of economic progress. This idea understand social progress such as a way to increasing GDP growth in the short term that implies to increase social and economic activities and jobs without considering negative effects for the future like the destruction of forest ecosystem, and consequently the landscape attraction for foreign tourists and also an high quality natural park next to the beach for local population. In fact, this case shows the change of paradigm about this way of understand the social and economic progress [14].

In contrast with this case there is the case of "La Manga del Mar Menor". This is a similar case also in a sand band between the inland lake of "Mar Menor" and Mediterranean Sea in Murcia department in Spain. This case was analysed by García-Ayllón [15], [17] and Miralles i Garcia and García-Ayllón [16]. It is also a project of touristic political developed in the 1960 s in Spain. In this case, like the others touristic projects promoted such as part of official touristic political in this period, was totally executed. The initial project (that was also inspired in proposals of Modern Architectural Movement and elaborated by Antonio Bonet, architect) was progressively transformed on a mass use of residential buildings that generated a very congested urban area without public or private facilities to support touristic activities and also without land to build facilities, infrastructures or equipment. Today only with urban renovation processes would be possible transforming the area to improve quality and facilities, solve environmental problems and maintain touristic activities with a level of quality.

Instead, in the exceptional case of "La Devesa", the majority of public works executed by city council were demolished and were developed several projects to rewilding the majority of area as you can see in Fig. 4 that show the promenade built before demolition and currently landscape with rewilding in process.

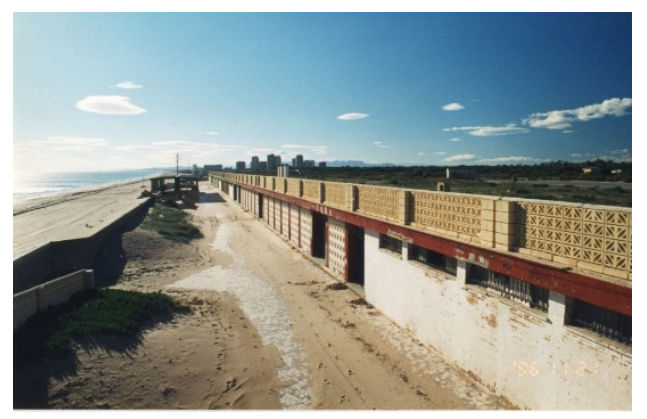

(a)

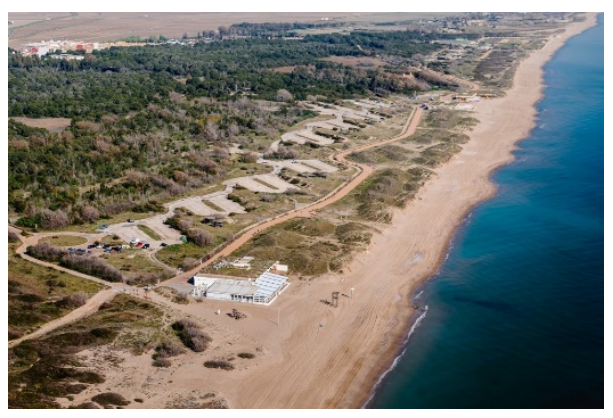

(b)

Figure 4: (a) Picture (taken in 1996) of the built promenade; and (b) Picture (taken in 2017) of the process of rewilding after the demolition of the promenade. (Source: Photographic Archive of Municipal Office "Devesa-Albufera".)

In addition, it is necessary remember the speculative real estate cycles that took places in Spain over three periods of time: 1960-1972, 1986-1992 and 1997-2007 [18], [19]. These speculative processes were caused mainly by the concept of land propriety to build regulated in Spanish laws. In fact it is contradictory to pay a large quantity of money for a good, the land to build (that is a bad name because the builder or construction company really need the 
underground to lay the foundation of buildings or public works, and this underground is a natural good not made by anyone) that really is a natural good. The fact of paying for a good that no one made or without no one added value made by anybody, impoverishes society, that is, enriches a few at the cost of impoverishing many that must pay for a product that nobody has really manufactured. In addition, often, people that became rich quickly by this method, instead of by productive economic activity, became an idol for a lot of people in society that want to do the same. In contrast, it has long been known that the only source of wealth is work [20].

\section{METHODOLOGY AND DATA}

This article shows a part of the results of a $\mathrm{PhD}$ research. Particularly about the following secondary objective or question: What should be the idea of society's progress when touristic urban development growth is no longer possible or desirable?

In fact, the case of "La Devesa" is a case where building this space to growth GDP is not possible because of environmental values of the "La Devesa" forest are more important than the economic activities produced through building the area. Valencian society decided by a democratic system rewilding this area. The majority of Valencian society preferred to build other spaces and maintain the ecosystem of "La Devesa". It is very difficult a comparative analysis of economic benefit for society between the two possible situation of "La Devesa" forest: building a touristic city or maintaining it use as natural ecosystem. However, on the other hand, is obviously that, to maintain social and economic activities in urban and metropolitan areas, it is necessary maintain the ecosystems (natural capital) that are producing the environmental services that society use to its own activities. In a general situation, where the expansion of urban and metropolitan areas can produce destruction of natural ecosystems inside them and, at the same time, it is necessary promote and maintain a green infrastructure as a way to sustainability, it is important to know how we can rewilding areas inside urban and metropolitan areas and which can be it economic cost.

In consequence, the research was focused to analyse the rewilding economic cost of the area of "La Devesa" forest.

According to Alía [21], the methodology used is that of scientific method for historical research focused to know the historical process, calculate the cost of building and rewilding and interpret historic acts generating a coherent social logic. In sum, the methodology has been: obtain historical data from different sources about public propriety sold, cost of public works, cost of rebuy plots, cost of demolition and cost of rewilding; semi-structured interviews to significant social agents with protagonist role in actions to identify data sources, obtain original documents, identify social agents and to know the difficulties and the process. You can see more detailed information in Doctoral thesis [1].

The main sources of historical data consulted have been the following:

- Historical bibliography;

- Historical documents about urban activities of city council, especially in Municipal Office Devesa-Albufera, Municipal Office of Urban Planning, Historic Municipal Archive of Valencia and Historic Archive of Valencian Community;

- Urban plans approved or previous studies;

- Rewilding projects;

- Laws applied at all times;

- Land propriety, especially by Public Utility Forest Catalogue, General Inventory of Municipal Properties of Valencia, Land Registry and others;

- Municipal Newspaper Archive of Valencia; 
- Brochures of activities or real estate developments;

- Documents of conferences and workshops.

\section{RESULTS AND DISCUSSION}

\subsection{Revenue and costs during building process}

At the beginning, land of "La Devesa" forest was propriety of Valencia City Council that obtained permission from "Ministerio de Gobernación" to sell plots for private buildings on 17 February 1970. The sale was undertaken by a public tender system. The first public tender to sell plots for building inside of "La Devesa" forest was done on 10 March 1970 and the last public tender was on 10 January 1973.

Between 1970 and 1973 a total of 410 plots were sold and Valencia City Council obtained an income of 457,345,945 pesetas (approximately 42,997,352 euros currently based on the exchange from 1973 pesetas to 1999 pesetas to 1999 euros to 2020 euros).

The total surface of plots sold was $394,899 \mathrm{~m}^{2}$ where a total of $1,345,800 \mathrm{~m}^{3}$ could be built on. Therefore, the average sale price of the right to build was 339.83 pesetas per cubic metre (approximately 31.95 euros per cubic metre) or $1,158.13$ pesetas per square metre of plot (approximately 108.88 euros per square metre of plot).

However, only 63 plots out of the 410 was built on, which equates to a total of 103,740 $\mathrm{m}^{2}$ of plots built according to the following distribution:

- Zone 1. Sidi Saler. Hotel, 1 plot, 200,000 $\mathrm{m}^{2}$.

- Zone 2. La Casbah. Residential area with single family homes, 36 plots, $12,604 \mathrm{~m}^{2}$.

- Zone 5. Aparwarks. Apartment towers, 5 plots, 2,718 $\mathrm{m}^{2}$.

Regarding the public works, 124 certificates of executed public works and 118 certificates of review executed public works have been found. The last certificate was signed in 1978 . Consequently we can consider that public works to urbanize the area finished in 1978. The final cost of public works was the following:

- Total public works certificated: 915,023,100 pesetas (approximately 31,456,565.65 euros, currently)

- Total price review of public works certificated: $373,574,248$ pesetas (approximately $12,842,695.80$ euros, currently)

- Management cost: 2,703,959 pesetas (approximately 92,956,41 euros, currently)

- Total urbanization cost: 1,291,301,307 pesetas (approximately 44,392,217.35 euros, currently)

- Interest for late payment of certifications: 95,786,418 pesetas (approximately 3,292,935.17 euros, currently)

- Total cost urbanization: 2,331,337,725 pesetas (approximately 80,146,477.39 euros, currently)

Considering that the income from selling plots was $1,264,130,620$ pesetas, Valencia City Council had a loss of 1,067,207,105 pesetas (approximately 36,688,330.99 euros, currently) as final result of real estate operation.

\subsection{Repurchase of plots between 1983 and 2003}

The 347 plots sold by Valencia City Council but not build on were repurchased by the first democratic local government. These 347 plots were occupying a surface of $291,159 \mathrm{~m}^{2}$ while 
the 63 plots built occupy a surface of $103,740 \mathrm{~m}^{2}$. Valencia City Council recovered the 347 plots without build throughout period 1983-2000.

Valencia City Council planned to recover the plots at the average price of 3,877.35 pesetas $/ \mathrm{m}^{2}$ calculated as initial sale price plus the increase of the cost of living.

The process of repurchase started in 1983 with the purchase of the first 106 plots by agreement with owners. The rest of the plots were recovered through legal proceedings and court decisions.

Finally in 2003 finished the recovered processes. The final cost of the 347 plots recovered was 2,254,791,846.3 pesetas (approximately 26,967,559.22 euros, currently). That is, the final average price of purchase was 7,744.19 pesetas per square metre (approximately 92.62 euros (currently) per square metre). Fig. 5 shows a detail of location of main plots recovered.

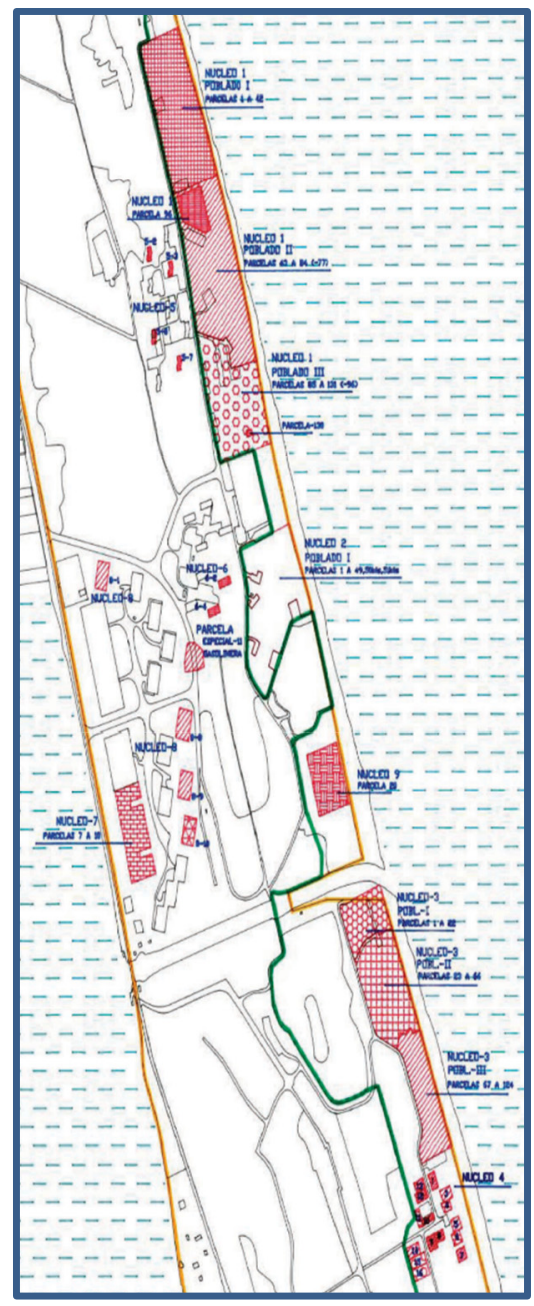

Figure 5: Detailed map with location of plots to recover. (Source: "Previous report about plots recovery inside 'La Devesa' forest', 2000, Heritage Inventory Office of Valencia City Council.) 
As a consequence, the total surface of segregated plots of initial only plot of "La Devesa" get down to $919,175.99 \mathrm{~m}^{2}$ distributed according to the following:

- National tourism parador and golf course $\left(723,436 \mathrm{~m}^{2}\right)$

- $\quad$ ICONA farm $\left(50,000 \mathrm{~m}^{2}\right)$

- Bull-fighting inn $\left(32,000 \mathrm{~m}^{2}\right)$

- Stevedores school $\left(10,000 \mathrm{~m}^{2}\right)$

- Residential zone 2 "La Casbah" $\left(12,603.99 \mathrm{~m}^{2}\right)$

- Residential zone 5 “Aparwarks" $\left(2,718 \mathrm{~m}^{2}\right)$

- Residential zone 6 $\left(3,654 \mathrm{~m}^{2}\right)$

All of recovered plots had been classified such as Open Spaces System in Valencia Urban Plan approved in 1988. This classification implies that these areas are public domain and cannot be built on.

In addition of public works demolition and plot recovery, Valencia City Council undertook several rewilding works to recovery natural soil and ecosystem. Table 1 shows the rewilding works executed. These natural restoration projects include demolition works of urbanization works.

Table 1: Rewilding areas inside "La Devesa" and cost. (Source: Vizcaíno et al. [22] and authors.)

\begin{tabular}{|l|c|c|}
\hline Intervention zone & Surface $\left(\mathrm{m}^{2}\right)$ & Cost (euros) \\
\hline Beach: El Canyar & 4,742 & $87,495.19$ \\
\hline $\begin{array}{l}\text { Beach: La Malladeta and La } \\
\text { Brava }\end{array}$ & 717,012 & $5,397,123.29$ \\
\hline $\begin{array}{l}\text { Beach: Els Ferros and La } \\
\text { Garrofera }\end{array}$ & 98,675 & $3,063,190.00$ \\
\hline Beach: El Saler & 60,000 & $9,486,330.82$ \\
\hline Municipal campsite: El Saler & 87,300 & $\mathrm{~ns} / \mathrm{nc}$ \\
\hline Sport area: El Saler & 52,000 & $849,405.00$ \\
\hline Wetland: Racó de 1'Olla & 243,430 & $1,147,933.12$ \\
\hline Total & $\mathbf{1 , 2 6 3 , 1 5 9}$ & $\mathbf{2 0 , 0 3 1 , 4 7 7 . 4 2}$ \\
\hline
\end{tabular}

Adding the debt generated by the urbanization works (6,414,044 euros), the final cost of the recovered plots $(26,967,559$ euros), the cost of demolition public works of the urbanization and the cost of restoration of habitats in "La Devesa" during the last three decades $(20,031,477$ euros), the total amount invested in rewilding action amounts to 53.4 million euros, currently. This quantity is an estimate or rough guess at the cost because of the difficulty to do a precise calculation with payments done in different times.

\section{CONCLUSIONS AND IMPLICATIONS}

The appraisal of "La Devesa" when was sale to the Valencia City Council in 1927 was calculated by capitalizing its annual income in 1911, in fact capitalizing their products at $4 \%$. That is, the value of the land of "La Devesa" before touristic development was associated with the yield of the goods it produced (fan palm, reed, sand reed, esparto grass, low wood, hunting).

This criterion was modified in 1964 by the Law that allowed its urbanization. It responded to a political strategy that consisted of favouring the sale of land for the massive urbanization 
of coast to promote tourism and obtain foreign currency. In the case of "La Devesa", the Valencia City Council itself (owner of the property) acted as developer of the urbanization works, seeking to offset the expenses derived from them with the income obtained from the sale of public land in the form of building plots.

In other words, the new value of the land was generated by the potential urban development that was attributed to it through the new urban plan. In this way, the value of the land depended exclusively on the price of the buildings that is possible to build (use above the ground). The operation was considered such as driver for economic development due to the jobs it should generate and the possibility of new touristic economic activity. A privileged land close to the city of Valencia was sold to participate in a kind of urban development that was being promoted throughout Spain and that supposedly should contribute to the enrichment of Valencian society. But in fact, the operation was of a characteristic speculative real estate transaction for the benefit above all of a minority of society, to the detriment of the general interest.

But Valencian society faced this criterion, claiming the environmental values of this space in an intuitive and emotional way. The citizen opposition to the urbanization that was destroying this place coincided with the birth of a collective conscience sensitized with the protection of the environment and the start of specific scientific production about "La Devesa", which has remained constant to today. The decision to recover and preserve "La Devesa" was made by the Local Government that emerged from the first democratic elections.

In other words, Valencian society claims the space of "La Devesa" such as a public and natural space of the city of Valencia based on parameters that are not directly economic and difficult to quantify, associated with the improvement of well-being generated by open spaces and protect ecosystems which we now know as green infrastructure. Currently, this environmental awareness of society is well established for the maintenance of the ecosystems of our planet. This idea did not exist at that time, but it has progressively consolidated in the imaginary of our society, increasingly committed to the environment.

The recovery of "La Devesa" meant to reject the economic benefit expected from the urban development and the responsibility of assuming an added cost for the recovery of the soil and its geomorphological restoration.

In fact, this case shows a change of paradigm about how understand the progress of society contrast the economic benefit (usually measurement by GDP) with other intangible benefit such as environmental quality or maintain an specific forest or ecosystem. It is very difficult to quantify these benefits to compare with economic benefits.

On the other hand, this case shows the difficulties of rewilding processes or urban renovation processes. In fact, in this case it was not possible recovery the built plots because it was too expensive. This fact focus the attention on the role of private propriety of land to build. In a situation which metropolitan areas are in expansion and there is the need of urban renovation to improve urban sustainability and develop green infrastructures, recovery urban plot to change it use is, currently, very expensive when, in fact, builders need the underground, that is a natural good, to build. But not only this, other problem especially important is the landowners' right when the building is demolished. Usually new builders or administration have to pay a lot of money for the rights to build associated to underground. In this conditions it is very difficult urban renovation processes. In fact, now in Spain, urbanize rural areas is cheaper than renovation old urban areas, although old urban areas have all kind of urban services.

This historical case contrast with also historical case of "La Manga" and allows to compare both models. In fact, "La Manga" model present a list of problems of degradation 
with very difficult and expensive solutions by urban renovation processes. Therefore, if the economic analysis of urban tourist project in a specific location is only a direct analysis costbenefit without consider rewilding cost of previous ecosystem services, really the measuring of progress by immediate increase of GDP is false because of the real cost has been transferred to the future.

This original research is focused in a rewilding or urban renovation case. The authors doesn't know other published researches about similar cases with analysis about economic costs. Therefore this research open new research lines:

- How can we calculate or measure the society progress including cost of maintaining ecosystems services necessaries to own social and economic activities?

- Can the cost of rewilding have a tool to include the real cost of projects that destroy naturals ecosystems and it ecosystem services?

- Is it possible to identify ecosystems that produces environmental services and to calculate it value as cost of rewilding after it destruction?

- Is it possible to identify a natural capital and its value in this way?

\section{ACKNOWLEDGEMENTS}

The authors wish to express their gratitude to the Municipal Devesa-Albufera Service, the Municipal Heritage Service and the Municipal Planning Service of Valencia city for their assistance in facilitating the consultation of the historical documents, which enabled the execution of the doctoral thesis, the origin of this paper.

\section{REFERENCES}

[1] Martínez Llorens, F., Devesa de l'Albufera: El cambio de paradigma en el turismo de masas de la ciudad de Valencia. PhD thesis, Universitat Politècnica de València, 2019. https://riunet.upv.es/handle/10251/121137. Accessed on: 6 May 2020.

[2] Vheeler, S.M., The evolution of built landscapes in metropolitan regions. Journal of Planning Education and Research, 27, pp. 400-416, 2008. www.//jpe.sagepub.com/ cgi/content/abstract/27/4/400. Accessed on: 20 Feb. 2017.

[3] Aguilera, F., Valenzuela, L.M. \& Botequilha-Leitão, A., Landscape metrics in the analysis of urban land use patterns: A case study in a Spanish metropolitan area. Landscape and Urban Planning, 99, pp. 226-238, 2011. www.sciencedirect.com/ science/article/pii/S0169204610002823. Accessed on: 20 Feb. 2017.

[4] Feria Toribio, J.M. \& Martínez Bernabeu, L., La definición y delimitación del sistema metropolitano español: permanencias y cambios entre 2001 y 2011. Revista Ciudady Territorio. Estudios Territoriales, 187, pp. 9-24, 2016.

[5] Miralles i Garcia, J.L., Environmental and territorial planning on coastal metropolitan areas. A methodological proposal for València (Spain). International Journal of Environmental Impacts, 2(1), pp. 1-16, 2019.

[6] Hamilton, S., Cultivating Nature: The Conservation of a Valencian Working Landscape, University of Washington Press: Seattle, 2018.

[7] European Commission, Communication from the Commission to the European Parliament, the Council, the European Economic and Social Committee and the Committee of the Regions. Green Infrastructure (GI): Enhancing Europe's Natural Capital. http://eur-lex.europa.eu/legal-content/EN/TXT/?uri=CELEX:52013DC0249. Accessed on: 14 Oct. 2019. 
[8] Miralles i Garcia, J.L. \& Altur Grau, V.J., Updated method of aptitude to sustainable urban development for including green infrastructure. International Journal of Sustainable Development and Planning, 11, pp. 970-979, 2016.

[9] Miralles i Garcia, J.L., Green infrastructure on the Mediterranean Valencian coast. International Journal of Sustainable Development and Planning, 11(3), pp. 227-235, 2016.

[10] Miralles i Garcia, J.L., Environmental management of peri-urban natural resources: L'Horta de València case study. WIT Transactions on Ecology and the Environment, vol. 192, WIT Press: Southampton and Boston, pp. 99-110, 2015.

[11] Temes, R. \& Moya, A., Typology of the transformations occurred in the peri-urban space of Huerta de Valencia. Evidence from North arch of Valencia. International Journal of Sustainable Development and Planning, 11(6), pp. 996-1003, 2016.

[12] Gielen, E., Riutort-Mayol, G., Palencia-Jiménez, J.S. \& Cantarino, I., An urban sprawl index based on multivariate and Bayesian factor analysis with application at the municipality level in València. Environment and Planning B: Urban Analytics and City Science, 45(5), pp. 888-914, 2018.

[13] Gielen, E., Costes del "Urban Sprawl” para la administración local, Publicacions de la Universitat de València: València, 2016.

[14] Miralles i Garcia, J.L. \& Martínez Llorens, F., Tourist development and planning on Valencian Mediterranean coast: The case of "La Devesa del Saler". WIT Transactions on Ecology and the Environment, vol. 217, WIT Press: Southampton and Boston, pp. 495-507, 2018.

[15] García-Ayllón, S., Retrospective analysis of urban development In the Spanish Mediterranean Coast. WIT Transactions on Ecology and the Environment, 179, pp. 291-302, 2013.

[16] Miralles i Garcia, J.L. \& García-Ayllón, S., The economic sustainability in urban planning: The case of La Manga. WIT Transactions on Ecology and the Environment, vol. 173, WIT Press: Southampton and Boston, pp. 279-290, 2013.

[17] García-Ayllón, S., La Manga case study: Consequences from short-term urban planning in a tourism mass destiny of the Spanish Mediterranean coast. Cities, 43, pp. 141-151, 2015

[18] Miralles i Garcia, J.L., Real estate crisis and sustainability in Spain. WIT Transactions on Ecology and the Environment, vol. 150, WIT Press: Southampton and Boston, pp. 123-132, 2011.

[19] Miralles i Garcia, J.L., El darrer cicle immobiliari al País Valencià. O el progrés de la misèria, Fundació Nexe: València, 2014.

[20] Smith, A., An Inquiry into the Nature and Causes of the Wealth of Nations, Vol. 1, 1776. https://books.google.es/books?id=C5dNAAAAcAAJ\&pg=PP7\&redir_esc $=y \# v$ $=$ onepage $\& q \& \mathrm{f}=$ true. Accessed on: 28 May 2020.

[21] Alía, F., Métodos de investigación histórica, Síntesis: Madrid, 2016.

[22] Vizcaíno, A. et al., La Devesa de l'Albufera de Valencia: un caso de restauración dunar. Restauración y gestión de sistemas dunares. Estudio de casos, ed. F.X. RoigMunar, Càtedra d'Ecosistemes Litorals Mediterranis, pp. 115-136, 2016. 